\title{
Perlindungan Hukum bagi Pengusaha Pemilik Tanah Akibat Musnahnya Tanah oleh Bencana Alam Dan Kaitannya dengan Pihak \\ Ketiga
}

\author{
Oleh: \\ Bagus Rahmanda \\ Fakultas Hukum Universitas Diponegoro \\ rahmandabagus@gmail.com
}

\begin{abstract}
Abstrack
Entrepreneurs generally have assets in the form of movable objects, either in the form of land or buildings. Legal protection for holders of land rights certificates is not separated from human rights, because every person has the right to recognition of legal certainty, ha-land certificate is a strong but not absolute proof of certificate, meaning that the land rights certificate guarantees legal certainty for the owner as long as the certificate: a) is issued in the name of the rightful person, $b$ ) the right to the land is obtained by good title, $c$ ) is physically controlled, and d) no other party can prove otherwise. Factual Article 18, Article 27 Letter b, Article 34 Letter $f$ and Article 40 Letter $f$ of Law Number 5 Year 1960 in conjunction with Article 52 and Article 55 Government Regulation Number 24 of 1997 states that rights to registered land can be erased without the willingness of the holder and without compensation fund from the state because it was canceled based on the judgment of the court judge or the land was destroyed due to natural disasters or revoked rights in the public interest (other than compensation). Natural disasters in this case Likuifaksi is the process of changing the soil conditions of sand that is saturated with water due to increased pore pressure the price becomes the same as the total pressure due to the occurrence of the dynamic load, so that the effective voltage of the soil becomes zero. Likuifaksi is a phenomenon where the soil loses a lot of strength and stiffness for a short time, but even though liquefaction is the cause of a lot of damage, death, and large economic losses. In the event that a certificate of land rights or a building that is pledged as collateral to a third party in this case is a bank for business development purposes, it is necessary to have legal protection for those who own the land affected by liquefaction. Therefore, normative legal research is conducted using a juridical approach which starts from the analysis of secondary data with the support of expert opinion. Based on the results of the above research, it is concluded and suggested that countries willing to provide legal protection to holders of land and environmental rights certificates explicitly by optimizing the potential of natural resources, human resources, science and technology available through: - Repositioning acquisition procedures certificate of land rights with effective and efficient research of juridical physical and juridical data so that legal certainty is to protect holders of land rights certificates from the threat of abolishing land rights resulting from liquefaction.
\end{abstract}

Keywords: legal protection, landowners, third parties, liquefaction

\section{Jurnal Gema Keadilan}




\begin{abstract}
Abstrak
Pengusaha pada umumnya memiliki aset berupa benda bergerak, bisa berupa tanah maupun bangunan. Perlindungan hukum terhadap pemegang sertipikat hak atas tanah tidak dipisahkan dengan hak azasi manusia, karena setiap orang berhak atas pengakuan jaminan kepastian hukum, Sertifikat ha katas tanah merupakan surat tanda bukti yang kuat tetapi tidak mutlak, artinya sertipikat hak atas tanah menjamin kepastian hukum bagi pemiliknya sepanjang sertipikat tersebut: a) diterbitkan atas nama yang berhak, b) hak atas tanahnya diperoleh dengan itikat baik, c) dikuasai secara fisik, dan d) tidak ada pihak lain dapat yang membuktikan sebaliknya. Faktual Pasal 18, Pasal 27 Huruf b, Pasal 34 Huruff dan Pasal 40 Huruff Undang-undang Nomor 5 Tahun 1960 juncto Pasal 52 dan Pasal 55 Peraturan Pemerintah Nomor 24 Tahun 1997 menyatakan bahwa hak atas tanah terdaftar dapat hapus tanpa kemauan pemegangnya dan tanpa dana santunan dari negara sebab dibatalkan berdasarkan putusan hakim pengadilan atau tanahnya musnah akibat bencana alam atau haknya dicabut untuk kepentingan umum (selain ganti rugi), Bencana alam dalam hal ini Likuifaksi merupakan proses perubahan kondisi tanah pasir yang jenuh air menjadi cair akibat meningkatnya tekanan air pori yang harganya menjadi sama dengan tekanan total oleh sebab terjadinya beban dinamik, sehingga tegangan efektif tanah menjadi nol. Likuifaksi adalah fenomena dimana tanah kehilangan banyak kekuatan (strength) dan kekakuannya (stiffness) untuk waktu yang singkat namun meskipun demikian likuifaksi menjadi penyebab dari banyaknya kerusakan, kematian, dan kerugian ekonomi yang besar. Dalam hal sertifikat hak atas tanah atau bangunan yang dijaminkan ke pihak ketiga dalam hal ini adalah bank guna keperluan pengembangan bisnis, maka perlu adanya perlindungan hukum terhadap para pengusa pemilik tanah tersebut yang terkena dampak likuifaksi. Oleh karena itu, diadakan penelitian hukum normatif menggunakan metode pendekatan yuridis yang bertitik tolak dari analisis data sekunder atas dukungan pendapat para ahli. Berdasarkan hasil penelitian tersebut di atas, maka disimpulkan dan disarankan agar negara berkemauan menyediakan perlindungan hukum terhadap pemegang sertipikat hak atas tanah dan lingkungannya secara eksplisit dengan mengoptimalkan potensi sumber daya alam, sumber daya manusia, ilmu pengetahuan dan teknologi yang tersedia melalui : - Reposisi prosedur perolehan sertipikat hak atas tanah dengan penelitian data fisik dan data yuridis yang efektif dan efisien secara yuridis sehingga berkepastian hukum untuk melindungi pemegang sertipikat hak atas tanah dari ancaman hapusnya hak atas tanah akibat dari likuifaksi.
\end{abstract}

Kata kunci: perlindungan hukum, pemilik tanah, pihak ketiga, likuifaksi 


\section{A. Pendahuluan}

Bencana alam merupakan peristiwa alam yang menyebabkan kerugian di berbagai sudut. Bencana alam ini dapat disebabkan karena murni kejadian alam maupun disebabkan karena adanya ulah manusia. Ada banyak sekali jenis bencana alam di dunia ini seperti gunung meletus, gempa bumi, banjir, tanah longsor, kebakaran hutan, dan lain sebagainya. Bencana- bencana alam tersebut sangat sering melanda di wilayah negara Indonesia.

Di Indonesia sering terjadi bencana tanah longsor, dikarenakan perubahan cuaca atau iklim di Indonesia seperti halnya musim kemarau yang panjang dan disusul dengan musim hujan yang tidak ada hentinya. Salah satu faktor penyebab iklim musim di Indonesia ini juga pola hidup manusia yang melebihi kemampuan alam dan perubahan arah angin yang melintasi Indonesia. Rotasi bumi dan revolusi bumi juga mempengaruhi perubahan iklim khususnya di Indonesia. Bentuk permukaan Bumi khususnya di Indonesia yang banyak pegunungan ini juga menjadi salah satu faktor penyebab longsor.

Akibat dari kejadian tersebut terjadi pengembangan rongga-rongga dalam tanah yang luar biasa, sehingga mengakibatkan banjir dimana-mana. Bermula dari tanah merekah di musim kering itu, air hujan akan masuk dan terakumulasi di bagian dasar lereng, sehingga menimbulkan gerakan lateral. Selain itu sudut lereng yang terjal atau mencapai kemiringan sekitar 150 hingga 180 derajat dapat menyebabkan kerusakan tanah karena adanya longsor. Tentu akibat paling pahit akan dialami oleh orang yang tinggal di sekitarnya. Indonesisa merupakan Negara kepulauan terbsesar di dunia, yang terdiri dari ribuan pulau-pulau dan ada pulau pulau besar yang dikelilingi oleh lautan. Selain memiliki kekayaan alam yang melimpah Negara kita juga memiliki potensi alam yang luar biasa yang dapat digunakan untuk keperluan masyarakat luas. Dalam bidang pertanahan yang subur sehingga berbagai macam tanaman dapat tumbuh dan berkembang di Indonesia. Karena terletak diantara 2 benua dan 2 samudra yaitu samudra pasifik dan atlantik, sehingga potensi bencana alam juga tidak dapat serta merta langsung dihindari. Pada akhir bulan September 2018 daerah Palu dan sekitarnya terkena bencana alam berupa likuifaksi. Dikutip dari wikipedia. Pengertian Pencairan tanah atau likuifaksi tanah (soil liquefaction) adalah fenomena yang terjadi ketika tanah yang jenuh atau agak jenuh kehilangan kekuatan dan kekakuan akibat

\section{Jurnal Gema Keadilan}


adanya tegangan, misalnya getaran gempa bumi atau perubahan ketegangan lain secara mendadak, sehingga tanah yang padat berubah wujud menjadi cairan atau air berat. Karena tanah berubah menjadi cairan maka paling beresiko adalah tempat yang memiliki tipe tanah berpasir, karena pasir cenderung memiliki pori atau rongga dan mudah untuk terkena tarikan. Hilangnya struktur tanah akibat kehilangan kekuatan atau kemampuan untuk memindahkan tegangan geser inilah yang disebut sebagai pencairan. (https://id.wikipedia.org/wiki)

Likuifaksi adalah bencana alam yang dampak dan pengaruhnya sangat besar, sehingga walaupun lokasi titik kerjadian tidak berada pada jarak yang lumayan jauh tetapi berakibat pada objek dan subjek hukum yang terkena dampak likuifaksi tersebut. Oleh karena itu, permasalahan utama yang hendak diteliti sebagai berikut:

1. Bagaimana perlindungan hukum pemilik tanah terhadap musnahnya tanah akibat adanya likuifaksi ?

2. Bagaimana dampak adanya likuifaksi terhadap pelaku bisnis dan kaitannya dengan pihak ketiga? 


\section{Metode Penelitian}

Penelitian ini merupakan penelitian hukum yang mendasarkan pada nilai-nilai, asasasas hukum serta peraturan perundangan. Peraturan perundangan merupakan bahan-bahan hukum positif sebagai jaminan kepastian hukum. Namun penelitian hukum tidak hanya berhenti di situ saja, masih membutuhkan asas-asas hukum serta nilai-nilai yang merupkan roh nya hukum positif. Di dalamnya termasuk keadilan, tugas dan fungsi negara, hakekat berlakunya hukum. Bahan-bahan hukum (primer, sekunder, dan tersier) yang terkumpul kemudian diinventarisir, dikategorisasikan untuk kemudian dilakukan penafsiran terhadapnya dengan tetap mendasarkan pada norma, asas-asas hukum, serta nilai-nilai yang berlaku. Pendekatan yang dilakukan dalam penelitian hukum ini sebagai berikut:

1. Pendekatan peraturan perundang-undangan dengan cara melakukan kajian terhadap aturan yang berlaku dan relevan dengan masalah bencana alam. Pendekatan ini lebih menekankan pada keharmonian undang-undang yang bersifat horisontal. Maknanya adalah untuk menemukan kepastian hukum, hak dan kewajiban, agar korban bencana alam mendapat perlindungan legalitas.

2. Pendekatan konsep, dilakukan bilamana hukum positif tidak ditemukan dalam suatu pengertian yang belum jelas dalam peraturan perundangan yang berlaku, prosedur dan mekanisme dalam perlindungan hukum. Pendekatan konsep ini didasarkan pada pendapat dari para pakar hukum (scholar) atau dari berbagai sumber lainnya.

Mengingat penelitian ini bersifat kajian langsung di lapangan dan kajian terhadap pengaturan mengenai kepastian hukum akibat musnahnya tanah karena bencana alam di Kota Palu, maka dibutuhkan input data sosiologis khususnya yang berkaitan dengan pengelolaan sampah elektronik. Oleh karena itu dibutuhkan pula bantuan penelitian sosial, yang dalam hal ini digunakan metode penelitian kualitatif. Wilayah penelitian ini adalah wilayah Kota Palu, dan sekitarnya serta DKI Jakarta. Teknik pemilihan informan dalam penelitian ini adalah snowball sampling yaitu dimana penentuan subjek maupun informan penelitian berkembang dan bergulir mengikuti informasi atau data yang diperlukan dari informan yang diwawancarai sebelumnya. Sumber data utama dalam penelitian kualitatif ialah kata-kata, dan tindakan selebihnya adalah data tambahan seperti dokumen dan lainlain. 


\section{B. Hasil dan Pembahasan}

\section{Perlindungan Hukum Pemilik Tanah Terhadap Musnahnya Tanah Akibat Adanya}

\section{Likuifaksi}

Bencana alam gempa dan likuifaksi yang terjadi di Palu, Sigi dan Donggala telah meluluhlantakkan bangunan maupun harta benda milik penduduk. Bahkan, di daerah seperti Palu, dan sekitarnya bangunan instansi pemerintah nyaris rata dengan tanah dan menghancurkan dokumen-dokumen penting. Korban yang saat ini selamat dari bencana alam tersebut, umumnya telah kehilangan rumah sebagai bangunan tempat tinggal. Mereka yang menjadi korban sekeluarga, harus meninggalkan aset dan harta benda. Namun, dikutip dari pendapat ahli hukum agraria Maria SW Sumardjono, tidak berarti korban bencana telah kehilangan hak milik atas tanah yang sebelum bencana menjadi milik mereka. Dalam beberapa tahun ke depan, pembenahan kota-kota di Palu dan sekitarnya akan berjalan. Sementara itu, harapan untuk korban gempa untuk dapat memiliki tanahnya kembali masih dimungkinkan. Hal ini disebabkan karena gempa bumi maupun tsunami merupakan bencana alam diluar kehendak manusia. Selain itu dalam Undang-undang No.5 Tahun 1960 tidak mengenal penghapusan hak milik atas tanah dikarenakan terjadinya bencana alam. Kecuali tanah penduduk yang terkena bencana tidak musnah, berarti masih terdapat caracara yang mungkin diupayakan oleh pihak korban untuk memiliki kembali tanahnya.

Menurut Wakil Ketua Badan Pertanahan Nasional (BPN), Maria SW Sumardjono bencana alam yang terjadi tidak serta merta menghilangkan hak atas tanah. Jika seseorang mempunyai hubungan hukum dengan tanah, tentunya akan dilindungi. Ada beberapa cara yang mungkin dilakukan oleh korban yang selamat, keluarga maupun ahli waris dari korban yang sudah meninggal. Menurut Maria, langkah awal sehubungan dengan kepemilikan tanah di daerah pasca gempa dimulai dari menyelamatkan dokumendokumen milik Kanwil/Kantor Pertanahan yang tersebar di daerah di Palu, Sigi dan Donggala. Apabila dokumen-dokumen di Kanwil setempat masih ada, maka menurutnya hal tersebut dapat mempermudah pihak korban untuk mengurus kembali status kepemilikan tanahnya. Sebab, tiap-tiap Kanwil pasti memiliki warkah-warkah yang akan digunakan sebagai bukti kepemilikan atas tanah. Selain melihat warkah yang ada, Kanwil

\section{Jurnal Gema Keadilan}


setempat akan kembali melakukan pengukuran. Apabila Kanwil BPN setempat ikut musnah dan sertipikat tanah hilang/musnah maka perlu pemetaan ulang terhadap tanah yang dimaksud. Selain itu, orang yang ingin mengakui hak atas tanahnya harus didukung pula oleh bukti-bukti yang bisa diperoleh dari Kepala Desa ataupun tetangga-tetangga setempat. Kelengkapan data-data pendukung tersebut digunakan untuk menghindari adanya kepemilikan ganda atas satu bidang/areal tanah. Namun, Maria menambahkan kalau sampai ada dua orang atau lebih yang memperebutkan areal tanah yang sama maka dapat ditempuh melalui jalur mediasi. Selain korban, ahli waris dari korban bencana yang telah meninggal juga dapat meminta hak kepemilikan atas tanahnya yang terdapat di daerah bekas bencana alam. Deputi Advokasi Konsorsium Pembaruan Agraria (KPA), Langkah awal yang harus dilakukan oleh BPN apabila situasi telah kembali pulih adalah melakukan identifikasi kepemilikan tanah sampai pada ahli waris maupun keluarga korban. Disamping itu identifikasi yang dilakukan oleh BPN harus meliputi pula sistem penggunaan tanah tersebut bencana alam terjadi. Apakah tanah tersebut digunakan untuk rumah tinggal, lahan usaha ataupun lahan pertanian. (https://id.wikipedia.org/wiki)

\section{Negara Hanya Pengelola}

Sementara itu, tentang kepemilikan tanah pasca gempa menurut Usep negara tidak dapat secara langsung menguasai tanah tersebut meskipun pemilik tanahnya sudah meninggal dunia. Kepemilikan tanah sebaiknya tetap dikembalikan ke masyarakat, Terlebih lagi untuk daerah yang masih dihuni oleh masyarakat adat. Sebab dalam hak masyarakat adat dikenal dengan sistem komunal dimana tanah tersebut tidak dapat dipisahkan dengan masyarakat adat yang ada. Dalam hal ini peran negara khususnya BPN tetap harus dijalankan. Peranan tersebut sebaiknya terbatas pada pengelolaan tanah bekas bencana saja bukan peralihan menjadi tanah negara. (Fuady Munir, 2017)

\section{Hubungan Hukum Akibat Musnahnya Tanah Karena Bencana Dengan Pelaku Usaha Yang Kaitannya Dengan Pihak Ketiga.}

Di daerah Palu, Sigi dan Donggala banyak terdapat pelaku bisnis, karena daerah tersebut berpotensi untuk pengembangan bisnis dan usaha. Sehingga banyak pelaku

\section{Jurnal Gema Keadilan}


bisnis yang mengembangkan bisnisnya dengan cara mengajukan pinjaman baik ke bank maupun lembaga pembiayaan non bank bahkan ke Pegadaian.

Dalam hal gadai, Ada istilah Anda tentang "rumah yang digadaikan dan disita oleh Pegadaian". Gadai adalah hak dari kreditor terhadap benda bergerak yang dijaminkan debitor. Sedangkan tanah dan apa yang didirikan di atasnya (dalam hal ini rumah) merupakan benda tidak bergerak karena sifatnya, termasuk segala sesuatu yang secara langsung atau tidak langsung, karena perbuatan alam atau perbuatan manusia, digabungkan secara erat menjadi satu dengan tanah itu. Jadi, misalnya sebidang pekarangan, beserta dengan apa yang terdapat di dalam tanah itu dan segala apa yang dibangun di situ secara tetap (rumah) dan yang ditanam di situ (pohon), terhitung buahbuahan di pohon yang belum diambil. Penjelasan lebih lanjut silakan Anda simak Mengenai Benda Bergerak dan Benda Tidak Bergerak. Karena rumah dan tanah merupakan benda tidak bergerak, maka tanah dan rumah bukan objek gadai, melainkan objek Hak Tanggungan. Penjelasan lebih lanjut tentang gadai silakan simak Hak Kreditur Jika Barang Gadai Dipinjam Debitur. Perlu diketahui bahwa Pegadaian tidak melayani pembiayaan dengan jaminan hak tanggungan atas tanah dan rumah. Berdasarkan Pasal 8 Peraturan Pemerintah Nomor 103 Tahun 2000 tentang Perusahaan Umum (Perum) Pegadaian, Pegadaian menyelenggarakan usaha (Fuady Munir, 2007)

a. penyaluran uang pinjaman atas dasar hukum gadai;

b. penyaluran uang pinjaman berdasarkan jaminan fidusia, pelayanan jasa titipan, pelayanan jasa sertifikasi logam mulia dan batu adi, unit toko emas, dan industri perhiasan emas serta usaha-usaha lainnya yang dapat menunjang tercapainya maksud dan tujuan Pegadaian dengan persetujuan Menteri Keuangan. (https://id.wikipedia.org/wiki)

\section{Hak Tanggungan dan Prinsipnya}

Sebagaimana dijelaskan di atas, lembaga jaminan yang tepat untuk menjaminkan tanah beserta rumah adalah Hak Tanggungan sesuai ketentuan Undang-Undang Nomor 4 Tahun 1996 tentang Hak Tanggungan Atas Tanah Beserta Benda-Benda yang Berkaitan dengan Tanah ("UU Hak Tanggungan”). Hak Tanggungan adalah hak jaminan yang dibebankan pada hak atas tanah sebagaimana dimaksud dalam Undang-Undang Nomor

\section{Jurnal Gema Keadilan}


5 Tahun 1960 tentang Peraturan Dasar Pokok-Pokok Agraria berikut atau tidak berikut benda-benda lain yang merupakan satu kesatuan dengan tanah itu, untuk pelunasan utang tertentu, yang memberikan kedudukan yang diutamakan kepada kreditor tertentu terhadap kreditor-kreditor lain. Sehingga kami asumsikan bahwa rumah yang hancur akibat gempa tersebut dibebankan dengan Hak Tanggungan untuk pelunasan utang Anda sebagai debitor terhadap kreditor. Bagaimana jika rumah hancur terkena bencana gempa? Apakah masih tetap dapat dilakukan lelang? Untuk mengetahui apakah tanah dan rumah tersebut tetap dapat dilelang, maka perlu kita ketahui apakah hak tanggungan yang menjadi dasar pelelangan jaminan tersebut masih ada atau tidak dengan hancurnya rumah. Merujuk pada ketentuan mengenai hapusnya hak tanggungan, sebagaimana diatur dalam Pasal 18 ayat (1) UU Hak Tanggungan, hak tanggungan hapus karena halhal sebagai berikut:

a. hapusnya utang yang dijamin dengan Hak Tanggungan;

b. dilepaskannya Hak Tanggungan oleh pemegang Hak Tanggungan;

c. pembersihan Hak Tanggungan berdasarkan penetapan peringkat oleh Ketua Pengadilan Negeri;

d. hapusnya hak atas tanah yang dibebani Hak Tanggungan.

Berdasarkan uraian tersebut, maka apabila rumah sebagai benda yang merupakan satu kesatuan dengan tanah itu hancur karena gempa bumi, maka tanahnya tetap ada atau dengan kata lain hak atas tanahnya tidak ikut hilang/hapus. Sehingga, pelelangan tetap dapat dilakukan meski rumahnya tidak ada. Perlu diingat juga bahwa dalam hal tanah dan rumah dijaminkan dengan Hak Tanggungan, esensinya yang menjadi jaminan adalah tanah beserta bangunan (maksudnya dalam hal ini rumah), jadi hilang atau rusaknya rumah tidak berarti jaminannya hilang karena tanahnya masih ada. Selain itu, pada umumnya dalam hal tanah dan rumah sebagai jaminan, kreditor akan meminta debitor mengasuransikan rumah tersebut. Kemudian, kreditor akan memperjanjikan uang pertanggungan asuransi (jika rumah hancur) akan diberikan kepada kreditor. Ini sehubungan dengan ketentuan dalam UU Hak Tanggungan yang mengatur dalam akta pemberian hak tanggungan dapat dicantumkan janji bahwa pemegang hak tanggungan akan memperoleh seluruh atau sebagian dari uang asuransi yang diterima pemberi hak

\section{Jurnal Gema Keadilan}


tanggungan untuk pelunasan piutangnya, jika obyek hak tanggungan diasuransikan. Sehingga jika terjadi gempa bumi, kreditor sebagai pemegang hak tanggungan akan memperoleh seluruh atau sebagian dari uang asuransi yang diterima oleh debitor. (Santoso, Urip, 2005)

\section{Lelang Objek Hak Tanggungan}

Dasar hukum lelang obyek Hak Tanggungan adalah Pasal 6 UU Hak Tanggungan yang berbunyi:

Apabila debitor cidera janji, pemegang Hak Tanggungan pertama mempunyai hak untuk menjual obyek Hak Tanggungan atas kekuasaan sendiri melalui pelelangan umum serta mengambil pelunasan piutangnya dari hasil penjualan tersebut.

Ketentuan lebih lanjut tentang pelaksanaan lelang terdapat dalam Peraturan Keuangan Nomor 27/PMK.06/2016 Tahun 2016 tentang Petunjuk Pelaksanaan Lelang Menteri ("Permenkeu 27/2016").

Sepanjang penelusuran kami, kami tidak menemukan aturan tentang akibat hukum pada lelang jika rumah sebagai bagian dari objek lelang hancur atau musnah. Yang ada adalah dalam hal terjadi keadaan memaksa, sebelum dilaksanakannya lelang atau setelah dimulainya lelang, maka dapat dilakukan pembatalan lelang Gempa bumi termasuk force majeure, yaitu kejadian atau keadaan yang terjadi di luar kuasa para pihak berkepentingan yang dapat juga disebut keadaan darurat. Force majeure ini biasanya merujuk pada tindakan alam (act of God), seperti bencana alam (banjir, gempa bumi), epidemik, kerusuhan, pernyataan perang, perang dan sebagainya. tanpa mengambil pelunasan piutang dari hasil pelelangan umum tersebut. (Bahsan, 2007

\section{Jurnal Gema Keadilan}




\section{Kesimpulan}

1. Bencana alam yang terjadi tidak serta merta menghilangkan hak atas tanah. Jika seseorang mempunyai hubungan hukum dengan tanah, tentunya akan dilindungi. Ada beberapa cara yang mungkin dilakukan oleh korban yang selamat, keluarga maupun ahli waris dari korban yang sudah meninggal. Menurut Maria, langkah awal sehubungan dengan kepemilikan tanah di daerah pasca gempa dimulai dari menyelamatkan dokumen-dokumen milik Kanwil/Kantor Pertanahan yang tersebar di daerah di Palu, Sigi dan Donggala. Apabila dokumen-dokumen di Kanwil setempat masih ada, maka menurutnya hal tersebut dapat mempermudah pihak korban untuk mengurus kembali status kepemilikan tanahnya. negara tidak dapat secara langsung menguasai tanah tersebut meskipun pemilik tanahnya sudah meninggal dunia. Kepemilikan tanah sebaiknya tetap dikembalikan ke masyarakat, Terlebih lagi untuk daerah yang masih dihuni oleh masyarakat adat. Sebab dalam hak masyarakat adat dikenal dengan sistem komunal dimana tanah tersebut tidak dapat dipisahkan dengan masyarakat adat yang ada. Dalam hal ini peran negara khususnya BPN tetap harus dijalankan.

2. Rumah sebagai benda yang merupakan satu kesatuan dengan tanah itu hancur karena gempa bumi, maka tanahnya tetap ada atau dengan kata lain hak atas tanahnya tidak ikut hilang/hapus. Sehingga, pelelangan tetap dapat dilakukan meski rumahnya tidak ada. Perlu diingat juga bahwa dalam hal tanah dan rumah dijaminkan dengan Hak Tanggungan, esensinya yang menjadi jaminan adalah tanah beserta bangunan (maksudnya dalam hal ini rumah), jadi hilang atau rusaknya rumah tidak berarti jaminannya hilang karena tanahnya masih ada. Selain itu, pada umumnya dalam hal tanah dan rumah sebagai jaminan, kreditor akan meminta debitor mengasuransikan rumah tersebut. Kemudian, kreditor akan memperjanjikan uang pertanggungan asuransi (jika rumah hancur) akan diberikan kepada kreditor.

\section{Jurnal Gema Keadilan}




\section{Daftar Pustaka}

\section{BUKU}

Harsono, Boedi., Hukum Agraria Indonesia. Djambatan.

Santoso, Urip, Hukum Agraria Kajian Komprehensif, Prenada Media Group, 2005

Arba, H.M.,Hukum Agraria Indonesia buku parna, Sinar Grafika, 2013

Kurniati, Nia, Hukum Agraria Sengketa Pertanahan, Refika Aditama, 2019

Trisadini P. Usanti, dan Somad Abdul.,Hukum Perbankan, PrenadaMedia , 2017

Hermansyah, Hukum Perbankan Nasional Indonesia, PrenadaMedia , Surabaya, 2014

Bahsan.,M.,Hukum Jaminan dan Jaminan Kredit Perbankan Indonesia, Rajawali Pers, 2007

Fuady, Munir, Hukum Jaminan Utang, Rajawali Pers, 2007

Fuady, Munir, Pengantar Hukum Bisnis : Menata Bisnis Modern di Era Global, Citra Aditya, 2008

Wijaya Andika, dan Wida Peace Ananta, Hukum Bisnis Properti Indonesia, Grasindo, Jakarta, 2017

\section{Jurnal}

Yusrial,M (2017) Perlindungan Hukum Pemegang Hak Atas Tanah Dalam Pengadaan Tanah Untuk Kepentingan Umum, Vol. 2, (No. 1)

Mamentu, Mirza (2017) perlindungan hukum terhadap pemegang sertifikat hak atas tanah berkaitan dengan adanya peristiwa alam gempa bumi menurut undangundang nomor 5 tahun 1960, Vol. 5, (No. 9)

Amalia, Rizki (2012) Perlindungan Hukum Bagi Pemegang Hak Atas Tanah Dalam Penetapan Ganti Rugi Terkait Dengan Pengadaan Tanah Untuk Kepentingan Umum, Vol. 27, (No. 3)

\section{Website}

(https://id.wikipedia.org/wiki)

\section{Jurnal Gema Keadilan}

